\title{
Variability of water vapour in the Arctic stratosphere
}

\author{
Laura Thölix ${ }^{1}$, Leif Backman ${ }^{1}$, Rigel Kivi ${ }^{2}$, and Alexey Yu. Karpechko ${ }^{3}$ \\ ${ }^{1}$ Climate Research, Finnish Meteorological Institute, Helsinki, Finland \\ ${ }^{2}$ Arctic Research, Finnish Meteorological Institute, Sodankylä, Finland \\ ${ }^{3}$ Arctic Research, Finnish Meteorological Institute, Helsinki, Finland \\ Correspondence to: Laura Thölix (laura.tholix@fmi.fi) \\ Received: 11 June 2015 - Published in Atmos. Chem. Phys. Discuss.: 17 August 2015 \\ Revised: 10 March 2016 - Accepted: 14 March 2016 - Published: 7 April 2016
}

\begin{abstract}
This study evaluates the stratospheric water vapour distribution and variability in the Arctic. A FinROSE chemistry transport model simulation covering the years 1990-2014 is compared to observations (satellite and frost point hygrometer soundings), and the sources of stratospheric water vapour are studied. In the simulations, the Arctic water vapour shows decadal variability with a magnitude of $0.8 \mathrm{ppm}$. Both observations and the simulations show an increase in the water vapour concentration in the Arctic stratosphere after the year 2006, but around 2012 the concentration started to decrease. Model calculations suggest that this increase in water vapour is mostly explained by transport-related processes, while the photochemically produced water vapour plays a relatively smaller role. The increase in water vapour in the presence of the low winter temperatures in the Arctic stratosphere led to more frequent occurrence of ice polar stratospheric clouds (PSCs) in the Arctic vortex. We perform a case study of ice PSC formation focusing on January 2010 when the polar vortex was unusually cold and allowed large-scale formation of PSCs. At the same time a large-scale persistent dehydration was observed. Ice PSCs and dehydration observed at Sodankylä with accurate water vapour soundings in January and February 2010 during the LAPBIAT (Lapland Atmosphere-Biosphere facility) atmospheric measurement campaign were well reproduced by the model. In particular, both the observed and simulated decrease in water vapour in the dehydration layer was up to $1.5 \mathrm{ppm}$.
\end{abstract}

\section{Introduction}

Water vapour is the most important natural greenhouse gas in the atmosphere, accounting for about half of the current greenhouse effect (Schmidt et al., 2010). Although the majority of water vapour resides in the troposphere, it has been highlighted that stratospheric water vapour variations may play an important role in the decadal-scale variability of the climate (Solomon et al., 2010). Recently the existence of a positive stratospheric water vapour feedback was shown based on observations, i.e. stratospheric water vapour increases with tropospheric temperature, which contributes to the climate sensitivity (e.g. Dessler et al., 2013). Therefore, investigating the changes in stratospheric water vapour abundance is valuable for the detection and attribution of the ongoing climate change.

Water vapour is also an important constituent in the stratospheric chemistry. It intensifies ozone destruction both by producing odd-hydrogen species, which can destroy odd oxygen, and by the formation of polar stratospheric clouds (PSCs), which enable efficient conversion of halogen reservoir species to halogen radicals (e.g. Solomon et al., 1986). In the winter polar vortex, water vapour can condense to form ice PSCs, i.e. type II PSCs. Increased water vapour may also affect the abundance of other PSC types as the formation of both NAT (nitric acid trihydrate; type Ia PSC) (Hanson and Mauersberger, 1988) and STS (supercooled ternary solution; type Ib PSC) (Carslaw et al., 1995) is dependent on nitric acid and water vapour concentrations. Furthermore, the reaction rates on/in STS depend on the composition of the particles, which is a function of water vapour (Sander et al., 2011, Sect. 5). 
Ice PSCs contribute only to a minor part of the chlorine activation. According to a model study by Kirner et al. (2015), $90 \%$ of the ozone depletion in the Antarctic spring is caused by halogen activation on liquid particles. In a model study of the Arctic winter of 2009/2010, Wohltmann et al. (2013) showed that chlorine activation on liquid aerosols alone explained the observed changes in the ozone column to within $10 \%$. The additional chlorine activation caused by ice PSCs is modest. However, when ice PSC particles sediment to lower altitudes, a reduction in water vapour, i.e. dehydration, occurs (Kelly et al., 1989). Sedimenting ice PSC particles also contribute to the denitrification (Hintsa et al., 1998), which can prolong the ozone depletion in the spring due to a slower conversion of active chlorine back to the reservoir species $\mathrm{ClONO}_{2}$.

The Arctic polar vortex is often less stable and maintains higher temperatures than its Antarctic counterpart, and thus ice PSCs and dehydration are seldom observed (Solomon, 1999). However, stratospheric water vapour is expected to increase due to warming of the tropical tropopause (Gettelman et al., 2009) and an increase in the atmospheric methane concentration, both consequences of climate change. This, in addition to the increased radiative cooling in the stratosphere due to the increase in $\mathrm{CO}_{2}$ and water vapour (Shindell et al., 1998), may lead to enhanced PSC formation. For example Rex et al. (2006) found an increase in PSC volume trend in the lower Arctic stratosphere during dynamically quiescent winters since 1960s (see also Dameris et al., 2014). However, the relationship between increasing greenhouse gas concentrations and increasing PSC occurrences remains a controversial issue (Rieder and Polvani, 2013; Langematz et al., 2014).

The combined effect of temperature and water vapour on ozone, through homogeneous and heterogeneous chemistry and dynamics, is complex. The result of a climate model study by Tian et al. (2009) indicated that the increased stratospheric water vapour would lead to an increase in the total column of ozone in the Arctic in the future despite increased active chlorine in the polar spring regions, while in the Antarctic the ozone recovery would be delayed. The evolution of stratospheric water vapour and its effect on the formation of PSCs are therefore of interest.

The stratospheric water vapour concentration is controlled by atmospheric dynamics and photochemistry. Its main sources are intrusion from the troposphere via the tropical tropopause (Brewer, 1949) and production through oxidation of methane and also molecular hydrogen (Bates and Nicolet, 1950; Le Texier et al., 1988). When rising air masses pass through the cold tropical tropopause region, moisture is removed due to freezing and sedimentation of particles (Brewer, 1949). The variability in the entry of water vapour into the stratosphere is largely controlled by the variability in the tropical cold point temperature. The oxidation of methane leads to the formation of water through a series of reactions. The reaction with $\mathrm{OH}$ is the dominating methane loss re- action through most of the stratosphere, while the reaction with excited oxygen becomes increasingly important above $30 \mathrm{~km}$, and photolysis is dominant above $65 \mathrm{~km}$ (Le Texier et al., 1988). In addition, the reaction with atomic chlorine has some significance as a sink for methane but also as a termination reaction of ozone-depleting cycles, especially in the Antarctic vortex where denitrification reduces the importance of the reaction between $\mathrm{ClO}$ and $\mathrm{NO}_{2}$ (Fahey et al., 1990).

Due to the cold tropical tropopause, only a small fraction of tropospheric water vapour propagates to the stratosphere. As a result, the stratosphere is very dry, but it exhibits considerable variability both in space and time. The exceptional dryness of the stratosphere makes observation of stratospheric water vapour challenging. Long-term time series of stratospheric water vapour are rare, which complicates the study of concentration trends. Frost point hygrometer soundings have been performed in Boulder, Colorado, since 1980 and for shorter periods of time also in other locations, including Sodankylä, Finland (Oltmans et al., 2000). Additionally, global data are available from satellite instruments but only for a limited time span, for example from the Microwave Limb Sounder (MLS) on board the Upper Atmosphere Research Satellite (UARS) (19911993) and the Earth Observing System on Aura (EOS-Aura) (2004-today) (e.g. Lambert et al., 2007). The Odin SubMillimetre Radiometer (Odin/SMR) and the Envisat Michelson Interferometer for Passive Soundings (Envisat-MIPAS) also provides global coverage on a daily basis. Moreover, the Stratospheric Aerosol and Gas Experiment II and III (Earth Radiation Budget Satellite (ERBS)-SAGE-II, Meteor-3MSAGE-III), Polar Ozone and Aerosol Measurement (Satellite pour l'Observation de la Terre-Polar Ozone and Aerosol Measurement (SPOT-4)-POAM III), the UARS Halogen Occultation Experiment (UARS-HALOE), the SCanning Imaging Absorption spectroMeter for Atmospheric ChartographY (Envisat-SCIAMACHY), Solar Occultation for Ice Experiment (The Aeronomy of Ice in the Mesosphere (AIM)-SOFIE), and the Science Satellite (SCISAT) Atmospheric Chemistry Experiment Fourier Transform Spectrometer (SCISAT-1-ACE-FTS) have measured stratospheric water vapour in the northern high latitudes, but the spatial and temporal coverage is limited.

Several studies have used these available measurements to look into water vapour trends, especially in the midlatitudes. Oltmans et al. (2000) analysed frost point hygrometer measurements above Boulder, Colorado, and reported a trend of about $+0.048 \pm 0.001 \mathrm{ppm} \mathrm{yr}^{-1}$ between 1980 and 2000 at the level of $18-20 \mathrm{~km}$. Randel et al. (2004) compared the Boulder data to the HALOE measurements and reported differences between the Boulder data set and HALOE water vapour data. The seasonal and interannual changes were comparable, but the long-term increase observed in soundings were not seen in HALOE data. Later Scherer et al. (2008) did corrections for the instrumental bias of the Boul- 
der frost point hygrometer data, updated the Boulder trend, and reported a trend of $+0.03-0.04$ ppm yr$^{-1}$ between 1980 and 2000 at the same altitude but noted a sudden drop in the stratospheric water vapour beginning in 2001. Hurst et al. (2011) presented a new trend analysis of the 30-year record of Boulder stratospheric water vapour measurements (19802010) and found a $+1.0 \mathrm{ppm}$ increase over that time period at $16-26 \mathrm{~km}$ altitude, with significant short-term variability. However, Hegglin et al. (2014) suggested, based on merged satellite data set, that the Boulder time series is not globally representative and instead reported negative trends in mid- and high latitudes at $16 \mathrm{~km}$ altitude between the end of the 1980s and 2010. Based on satellite and sounding measurements, Solomon et al. (2010) reported negative trends in Boulder and generally in the midlatitudes at $18 \mathrm{~km}$ altitude between 2000 and 2009, while Hegglin et al. (2014) showed that these negative trends are mainly related to the sudden drop in the water vapour in 2000 and that after a few years with very low water vapour mixing ratios a recovery started in 2005. Recently Urban et al. (2014) reported another drop in the tropical water vapour during 2011-2012.

On the other hand, due to the lack of long-term time series, there have been very few studies of stratospheric water vapour trends in the Arctic, where variations in the water content can have large effects on springtime ozone depletion. Hegglin et al. (2013) have compared water vapour climatologies from 13 satellite products within the Stratospheretroposphere Processes And their Role in Climate (SPARC) data initiative and also analysed the anomalies in the northern extratropics water vapour. They found that the uncertainty in water vapour increases toward the polar regions, the mesosphere and the upper-troposphere-lower-stratosphere (UTLS) region. Hegglin et al. (2014) showed water vapour trends up to $80^{\circ} \mathrm{N}$ latitude for the time period between the late 1980s and 2010 and reported negative trends in the lower stratosphere. On the other hand, one should keep in mind that the coverage before 1998, which was based on HALOE and SAGE II, was not optimal, which warrants some caution regarding the results.

In this study, we use the FinROSE chemistry transport model (FinROSE-CTM) (Damski et al., 2007; Thölix et al., 2010) to investigate the stratospheric water vapour in the Arctic for the period 1990-2014. The model is described in Sect. 2. In Sect. 3 we describe the water vapour distribution in FinROSE simulations and observations. The modelled water vapour is evaluated against soundings at Sodankylä, Finland $\left(67.4^{\circ} \mathrm{N}, 26.6^{\circ} \mathrm{E}\right)$, and MLS satellite observations. The studied period includes the exceptionally cold January 2010 Arctic vortex with large-scale ice PSC formation, which was observed also by the Cloud-Aerosol Lidar with Orthogonal Polarization (CALIOP), the primary instrument onboard the Cloud-Aerosol Lidar and Infrared Pathfinder Satellite Observations (CALIPSO) space-borne lidar (Pitts et al., 2011). Section 4 shows the long-term variations of water vapour and its sources. Section 5 describes the dehydration frequency in the Arctic stratosphere from 1990 to 2014. Section 6 deals with the Arctic winter of 2010 , including results from the Lapland Atmosphere-Biosphere Facility (LAPBIAT-2) measurement campaign in January-March 2010.

\section{Modelling and data}

\subsection{FinROSE}

The FinROSE-CTM (Damski et al., 2007) is a global offline chemistry transport model describing the stratosphere and mesosphere. The model produces the distribution of 36 species, and the chemistry scheme consists of 110 gas phase reactions and 37 photodissociation processes. Water vapour is produced from the oxidation of methane and molecular hydrogen. The PSC scheme includes liquid binary aerosols (LBAs), STS (type Ib), solid NAT (type Ia), and ice (ice, type II) PSCs. Altogether, the model chemistry includes 30 heterogeneous reactions on/in liquid binary aerosols and type $\mathrm{Ia}, \mathrm{Ib}$, and II PSCs. Particle sedimentation, leading to dehydration and denitrification of the stratosphere, is also included in the model. The heterogeneous chemistry scheme in FinROSE is based on the calculation of the composition and volume of sulfate aerosols and PSCs and the partitioning of species between gas phase and condensed phase. The composition of LBA and STS is calculated using the method by Carslaw et al. (1995). The STSs are not considered below the ice PSC formation temperature. The number density profile for LBA and STS is estimated from McLinden et al. (1999), and the sulfuric acid distribution $\left(\mu \mathrm{m}^{2} \mathrm{~cm}^{-3}\right)$ is based on 2-D model data (Bekki and Pyle, 1992). NAT formation is based on the thermodynamic equilibrium equations by Hanson and Mauersberger (1988). The model includes an option to include a supersaturation requirement for NAT and ice formation, but this option was not used in the simulations reported in this paper. The choice was made due to the relatively modest resolution of the model. Coexistence of NAT and STS is allowed. A scheme for the growth of NAT particles is included based on Fahey et al. (2001). The number density of NAT particles is initially assumed to be $1 \mathrm{~cm}^{-3}$ (Krämer et al., 2003). For large NAT particles the number density is reduced. The temperature threshold for ice particle formation is based on expressions by Marti and Mauersberger (1993). The equilibrium pressure of nitric acid above ice is calculated according to Hanson and Mauersberger (1988). The ice number density is assumed to be $0.04 \mathrm{~cm}^{-3}$, as estimated from synoptic-scale PSCs (Dye et al., 1992).

The chemical kinetics used in this work follow the recommendations by Sander et al. (2011) and Atkinson et al. (2007). Photodissociation coefficients were calculated using the PHODIS radiative transfer model (Kylling et al., 1997) and were used in the model through look-up tables. The model transport is calculated using a flux-form semilagrangian transport scheme (Lin and Rood, 1996). 
The tropopause height is calculated at every time step using potential vorticity as defining parameter. Model levels below $\pm 2 \mathrm{PVU}$ are considered to be in the troposphere. The $380 \mathrm{~K}$ potential temperature level is used to define the tropopause height between $20^{\circ} \mathrm{S}$ and $20^{\circ} \mathrm{N}$. The tropopause thus changes with time depending on meteorological conditions. The tropospheric concentrations of the chemical species are not calculated in the model but prescribed via model boundary conditions. Tropospheric water vapour and ozone were obtained from the European Centre for Medium-range Weather Forecasts (ECMWF) ERAInterim reanalysis (Simmons et al., 2007; Dee et al., 2011). Tropospheric methane $\left(\mathrm{CH}_{4}\right)$ is from GLOBALVIEW data (ftp://aftp.cmdl.noaa.gov/products/globalview/ch4/), nitrous oxide $\left(\mathrm{N}_{2} \mathrm{O}\right)$ from Advanced Global Atmospheric Gases Experiment (AGAGE) data (Prinn et al., 2000), and halogens (Cly and Bry) are from Montzka et al. (1999) updated data. Carbon dioxide $\left(\mathrm{CO}_{2}\right)$ is based on global annual mean trend data (ftp://aftp.cmdl.noaa.gov/products/trends/co2). At the upper model boundary $(0.1 \mathrm{hPa})$, climatological values averaged over 2005-2014 from MLS data were used for water vapour and ozone. The model also has a tracer aimed at water vapour studies; this is a chemically passive tracer for describing the amount of water vapour entering through the tropopause.

In this study, the model was run with a horizontal resolution of $6^{\circ} \times 3^{\circ}$ (longitude $\times$ latitude) at 35 hybrid sigma levels, from the surface up to $0.1 \mathrm{hPa}$ (about $65 \mathrm{~km}$ ). The wind, temperature, and surface pressure fields were obtained from the ECMWF ERA-Interim reanalysis (Dee et al., 2011).

\subsection{Water vapour and PSC measurements}

High-resolution soundings of stratospheric water vapour from northern high latitudes are rare. However, such measurements have been made at Sodankylä $\left(67.4^{\circ} \mathrm{N}, 26.6^{\circ} \mathrm{E}\right)$, northern Finland, since early 2000 (Vömel et al., 2007a, c). The Sodankylä site is representative of high-latitude conditions in northern Europe, and the upper air soundings in winter and spring sample air both inside and outside the polar stratospheric vortex. Here we have used stratospheric water vapour measurements from two atmospheric sounding campaigns and some additional soundings obtained outside the major campaigns. The first set of sounding observations large enough to derive some statistics of water vapour vertical distribution was obtained during the LAPBIAT Upper Tropospheric Lower Stratospheric Water Vapour Validation Project (LAUTLOS-WAVVAP) campaign in early 2004 (e.g. Deuber et al., 2005; Vömel et al., 2007c; Karpechko et al., 2007; Suortti et al., 2008). The second campaign (the LAPBIAT2 Atmospheric Sounding Campaign) took place in JanuaryMarch 2010 (Kivi et al., 2010; Khaykin et al., 2013; Engel et al., 2014; Grooß et al., 2014). During these campaigns two types of frost point hygrometers were flown. The NOAA frost point instrument (Oltmans, 1985; Vömel et al., 1995) was flown during the first campaign, while the Cryogenic Frost point Hygrometer (CFH) was deployed during both campaigns. $\mathrm{CFH}$ is a well-characterized instrument capable of accurate water vapour measurements in the lower stratosphere typically up to the altitude of $25-28 \mathrm{~km}$ (Vömel et al., 2007 a, b). In this study we have used, in total, 13 NOAA and $\mathrm{CFH}$ frost point hygrometer profiles obtained during the first campaign and $13 \mathrm{CFH}$ soundings obtained during the second atmospheric sounding campaign. In addition we included eight NOAA or CFH soundings outside the main campaign periods, in order to improve temporal coverage. These additional soundings were made during January-February in the years 2003, 2006, 2008, 2013, and 2014.

In addition to the balloon soundings, observations from the MLS on board the Aura satellite provide global profile measurements of $\mathrm{H}_{2} \mathrm{O}$, temperature, and several trace gases (Lambert et al., 2007). In this study, we use the MLS version 3.3 Level 2 data, which are available from August 2004 to the present. The data are published in EOS MLS Science Team (2011), and they are accessed at http://disc.sci.gsfc. nasa.gov/datacollection/ML2H2O_V003.html. The Level 2 data are produced on pressure surfaces from 316 to $0.1 \mathrm{hPa}$ with a vertical resolution of about $3 \mathrm{~km}$. Each day about 3500 vertical profiles are measured along a sun-synchronous suborbital track. For Sodankylä we used MLS overpass data from the Aura validation data centre. All profiles within $300 \mathrm{~km}$ from Sodankylä were averaged to obtain daily profiles of water vapour. We also used polar stratospheric cloud observations provided by CALIPSO space-borne lidar (Pitts et al., 2007). The CALIPSO PSC algorithm classifies PSCs by composition. Six different classes are defined: STS; three classes of liquid-NAT mixtures; and two classes of water ice (synoptic-scale ice and wave ice) (Pitts et al., 2011). We used these CALIPSO PSC composition classes for calculating the areas where PSCs were observed. The area is calculated separately for ice and NAT. Both water ice and wave ice are included in the ice area and all the NAT mix classes are included in the NAT area. CALIPSO data are available from June 2006 to the present.

\section{Water vapour distribution}

The FinROSE-CTM has been run using ERA-Interim meteorology and ERA-Interim water vapour data as a tropospheric boundary condition. Thus, the evolution of water vapour in the FinROSE model is strongly constrained by the water vapour at the ERA-Interim tropopause. Kunz et al. (2014) recently compared ERA-Interim water vapour in the UTLS against independent sounding observations and found that while in the majority of the cases the agreement is satisfactory, in some cases the discrepancies between ERA-Interim and observations are large. Thus, one can expect that these biases would affect FinROSE simulations in the stratosphere. Nevertheless, since the description of stratospheric $\mathrm{H}_{2} \mathrm{O}$ in 
the ECMWF model is simplified (Monge-Sanz et al., 2013), the chemistry scheme in FinROSE produces a more realistic water vapour distribution, as we show in this paper.

First, we evaluated the simulated stratospheric water vapour distribution from FinROSE against measurements above Sodankylä. Figure 1 shows simulated and measured climatologies of water vapour distribution over Sodankylä between 2004 and 2014. Overall, FinROSE (top panel) is capable of reproducing the MLS observations (middle panel) of water vapour concentration and its vertical and temporal distributions. The maximum values of water vapour are located at the same altitude in both data sets. The largest differences are between 10 and $1 \mathrm{hPa}$ : in winter and spring the concentration in FinROSE is about 1 ppm higher compared to the MLS but in summer the MLS is about $0.3 \mathrm{ppm}$ moister than FinROSE. In comparison, the ECMWF ERAInterim reanalysis (bottom panel) clearly underestimates the observed water vapour concentrations in the upper stratosphere by $1 \mathrm{ppm}$, which is likely due to a relaxation of water vapour towards an equivalent value applied in ERA-Interim at the stratopause (Dethof, 2003). The lower stratosphere compares well with the MLS. The dryness in the reanalysis data is likely a consequence of cold bias in the tropics in the ERA-Interim data (Schoeberl et al., 2012). Also, the methane parameterization in the ECMWF model leads to air that is too dry (Dethof, 2003). It is also possible that too fast a general circulation previously identified in the ECMWF model causes reduced moisture in the polar regions (Simmons et al., 1999; Schoeberl et al., 2012; Monge-Sanz et al., 2013). Note that these problems with the general circulation affect FinROSE simulations because ERA-Interim meteorology is used. However, the full chemistry of FinROSE improves the water vapour distribution of the model. During winter and spring the very top levels of ERA-Interim are too moist compared to observations. This is probably due to too low a model upper boundary; the ECMWF model does not extend to the upper mesospheric altitudes where photochemical processes destroy water vapour causing the observed dry upper stratosphere. This process is also missing from FinROSE; however, it has been indirectly included by using a water vapour climatology calculated from MLS data as an upper boundary condition. Overall, Fig. 1 shows that FinROSE is capable of simulating the distribution and magnitude of stratospheric water vapour in the high northern latitudes, which gives us confidence in its applicability for a more detailed study of water vapour distribution, sources, and long-term variability.

For a more detailed comparison of model results with observations at northern high latitudes, we calculated the average mixing ratios and standard deviations of water vapour profiles above Sodankylä from the FinROSE model, ERAInterim, and observations. We chose January-February because of the availability of balloon soundings during this time. In this comparison ERA-Interim and FinROSE data are available daily from all the months of January and February
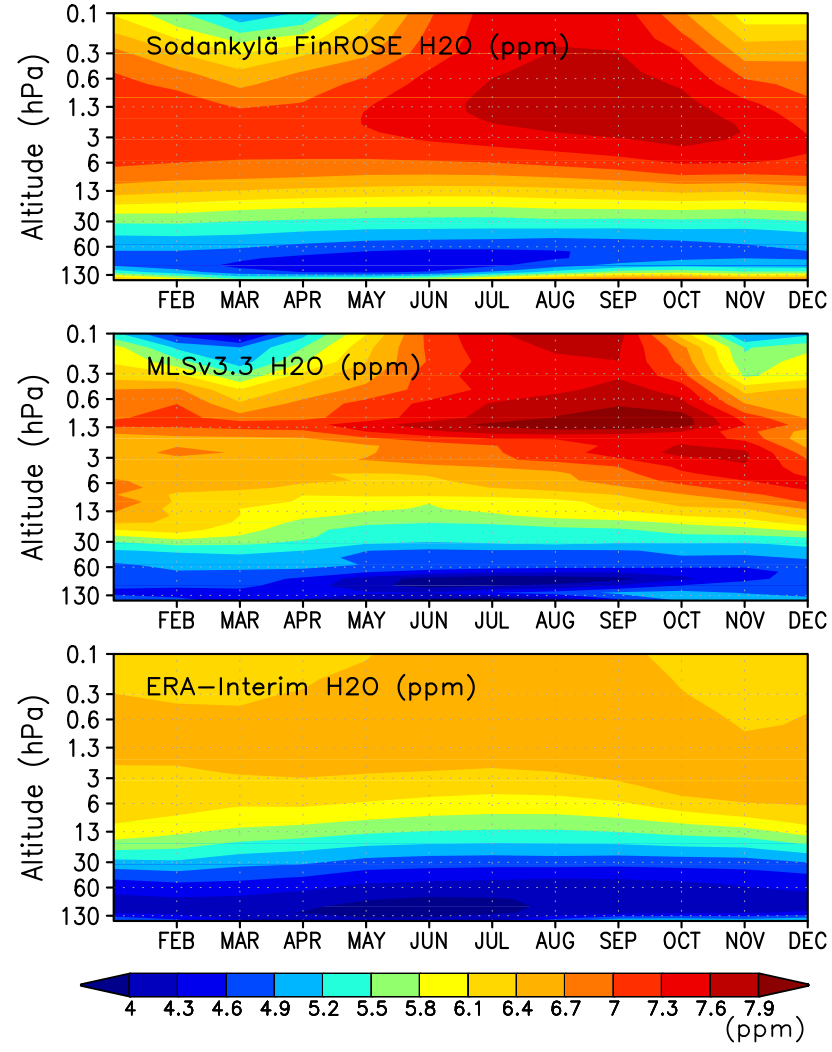

Figure 1. Climatology (2004-2014) of the water vapour distribution from FinROSE, MLS v3.3 data, and ECMWF ERA-Interim above Sodankylä.

between 2004 and 2013 and MLS data are available almost daily, but soundings are available less frequently (altogether 34 profiles). From FinROSE and ERA-Interim, the grid point closest to Sodankylä has been chosen $\left(30^{\circ} \mathrm{E}, 69^{\circ} \mathrm{N}\right)$. From the MLS all the profiles measured within $300 \mathrm{~km}$ from the Sodankylä grid point and flagged as good quality are used. Standard deviation is calculated across the individual profiles for each data set and thus represents uncertainty due to natural variability and random measurement errors. Figure 2 compares January-February mean water vapour mixing ratios and standard deviations above Sodankylä from the FinROSE simulation (black), ECMWF ERA-Interim reanalysis (green), MLS satellite measurements (blue), and frost point hygrometer soundings (red). The data are shown for seven different pressure levels; 100, 56, 30, 21, 10, 3, and $1 \mathrm{hPa}$. The left panel shows the mixing ratios in the winter of 2010 , and the right panel shows the relative differences compared to MLS observations calculated over the winters of 20052014. The winter of 2010 was chosen for comparison because of the largest amount of soundings.

The modelled water vapour concentration profile agrees well with MLS measurements in the winter of 2010 (shown in Fig. 2, left panel). The model data are within 0-0.5 ppm of the MLS data, except at $3 \mathrm{hPa}$ where the model gives $0.8 \mathrm{ppm}$ 

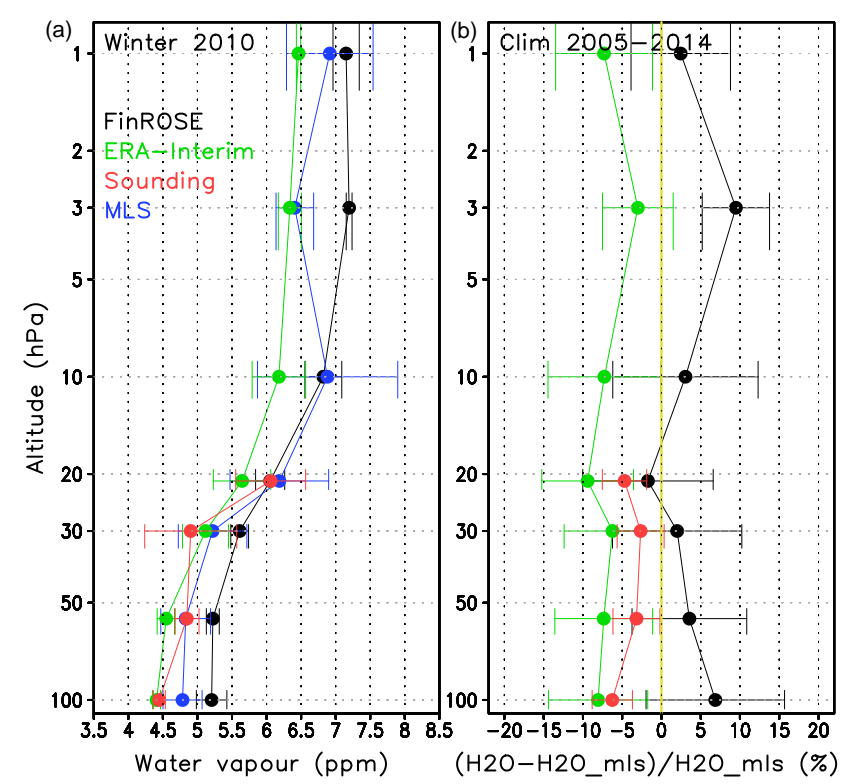

Figure 2. Panel (a): 2010 mean January and February water vapour mixing ratio and standard deviation above Sodankylä as a function of pressure. Panel (b): difference of the modelled or observed winter water vapour mixing ratio and the MLS calculated over the years 2005 to 2014 above Sodankylä as a function of pressure. FinROSE (black), MLS (blue), ECMWF ERA-Interim (green), and soundings (red).

more water vapour. Compared to the Sodankylä soundings, FinROSE has about $0.7 \mathrm{ppm}$ more water vapour at $100 \mathrm{hPa}$, but the difference decreases with altitude, except at $30 \mathrm{hPa}$ altitude where the model is again about $0.7 \mathrm{ppm}$ moister. At the levels between 100 and $21 \mathrm{hPa}$ the soundings fit the range of variation of the MLS. The difference is less than $0.5 \mathrm{ppm}$. Balloon sounding data are not available above $20 \mathrm{hPa}$. ERAInterim is generally drier compared to the MLS and soundings throughout the studied altitude range. ERA-Interim water vapour concentration is also always about $0.7 \mathrm{ppm}$ lower than FinROSE's which is consistent with Fig. 1.

The right panel shows the differences between models and observations averaged over several winters. The differences have been calculated using all the available data pairs during January and February between 2004 and 2014 and then averaged. For FinROSE and ECMWF all the MLS profiles have been used, but for sounding, only the coincident MLS profiles were used. The differences between FinROSE and the MLS, ERA-Interim and the MLS, and soundings and the MLS remain smaller than $10 \%$ at all altitudes. ERA-Interim is drier than the MLS also in this climatology, but FinROSE is moister than the MLS except at the $21 \mathrm{hPa}$ level. Soundings are also drier compared to the MLS, but the difference is smaller than the difference between ERA-Interim and the MLS. Sounding versus model comparisons are complicated because firstly the number of soundings is limited and, secondly, some of the soundings are obtained in the vicinity of
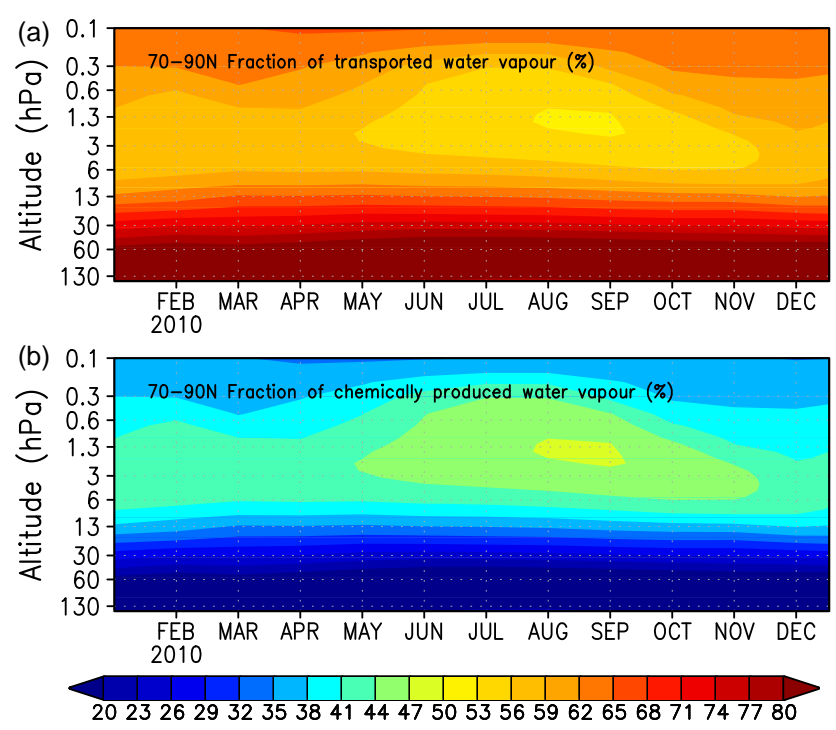

Figure 3. Monthly mean of (a) fraction of transported water vapour and (b) fraction of chemically produced water vapour (\%) for 2010 calculated over $70-90^{\circ} \mathrm{N}$.

the stratospheric vortex where the spatial water vapour gradients are large.

\section{The origin and long-term variability of water vapour}

The sources of stratospheric water vapour are transport from the tropical troposphere and chemical production mainly from methane oxidation. Water vapour enters the stratosphere through the tropical tropopause and propagates then to the upper altitudes and higher latitudes. The FinROSE model has a tracer for studying these two water vapour sources. A passive $\mathrm{H}_{2} \mathrm{O}$ tracer that is not affected by chemistry represents the transported water vapour. The difference between $\mathrm{H}_{2} \mathrm{O}$ tracer and $\mathrm{H}_{2} \mathrm{O}$ represents the amount of water vapour produced by chemistry, i.e. mainly through oxidation of methane but also hydrogen. Figure 3 shows the fractions of water vapour due to transport (upper panel) and chemistry (lower panel) according to simulations. Transport from the troposphere covers more than half of the water vapour. At lower altitudes the transported part is clearly the most important one. The chemically produced water vapour becomes more important at higher altitudes, with a maximum between 1 and $3 \mathrm{hPa}$. In the summer and autumn, the fraction of the chemistry part reaches almost $50 \%$ there.

The water vapour variability and trends above Sodankylä were investigated with a FinROSE model simulation covering the years 1986-2014. The first 4 years were discarded as spin-up, and the period 1990-2014 is analysed below. Figure 4 compares monthly mean water vapour mixing ratios at $56 \mathrm{hPa}$ above Sodankylä from the FinROSE simulation, ECMWF ERA-Interim reanalysis, and MLS satellite measurements. The red dots denote individual sounding 


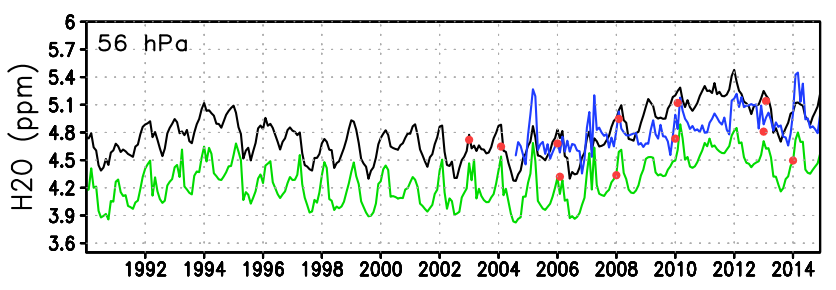

Figure 4. Sodankylä monthly mean water vapour mixing ratio from FinROSE (black), MLS (blue), ECMWF ERA-Interim (green), and soundings (red dots) at $56 \mathrm{hPa}$ between 1990 and 2014.

measurements. Throughout the investigated period, the water vapour amount in FinROSE and the observations varies within about 4-5.5 ppm. The modelled water vapour concentration agrees well with MLS measurements from 2005 to 2008; however, after that FinROSE shows higher concentrations than observed by the MLS and thus reveals a stronger increasing trend in these last 4 years. The growth rate is about $1 \mathrm{ppm}_{\text {decade }}{ }^{-1}$ in FinROSE but only $0.6 \mathrm{ppm}^{-1 e c a d e^{-1}}$ in the MLS. As can be expected based on Fig. 1, the ERAInterim water vapour concentration is about $0.5 \mathrm{ppm}$ lower than in FinROSE. It is, however, noteworthy that the difference remains approximately the same throughout the study period. The increasing trend from 2007 to 2012 is very similar in FinROSE and ERA-Interim data, resulting from the use of ERA-Interim meteorology as driver data in the FinROSE simulation.

Figure 5 shows the anomaly of FinROSE water vapour and the sources of it between latitudes $70-90^{\circ} \mathrm{N}$. All the anomalies in the figure are calculated with respect to the mean values for the period 1990-2014 for FinROSE and ERA-Interim and for the period 2004-2014 for MLS anomalies. The altitudes of the panels are $1,10,56$, and $100 \mathrm{hPa}$. At all the levels there are small positive trends in the water vapour from the beginning of the time series until the years 1994-1995. In the lower stratosphere $(100-56 \mathrm{hPa})$ the anomalies decrease until 1998 and then stay constant until 2007. Thereafter, a strong increase lasted until 2012, followed by another decrease, in agreement with observations by Urban et al. (2014) in the tropics. In the upper stratosphere $(10-1 \mathrm{hPa})$, the water vapour decreased from 1995 until about 2004 before starting to increase around 2007. At $10 \mathrm{hPa}$ the increase stopped by the end of 2013, but at $1 \mathrm{hPa}$ it did not stop until the end of the time series. Since the air in the upper polar stratosphere is older than that in the lower stratosphere (Stiller et al., 2012), the delay between water vapour changes in the lower and upper stratosphere suggests that these changes are driven by transport processes, consistent with our tracer results, which attribute most of the water vapour changes to dynamical processes.

In FinROSE simulations the long-term change in stratospheric water vapour in the high northern latitudes is positive. The simulated water vapour trends for midlatitudes and
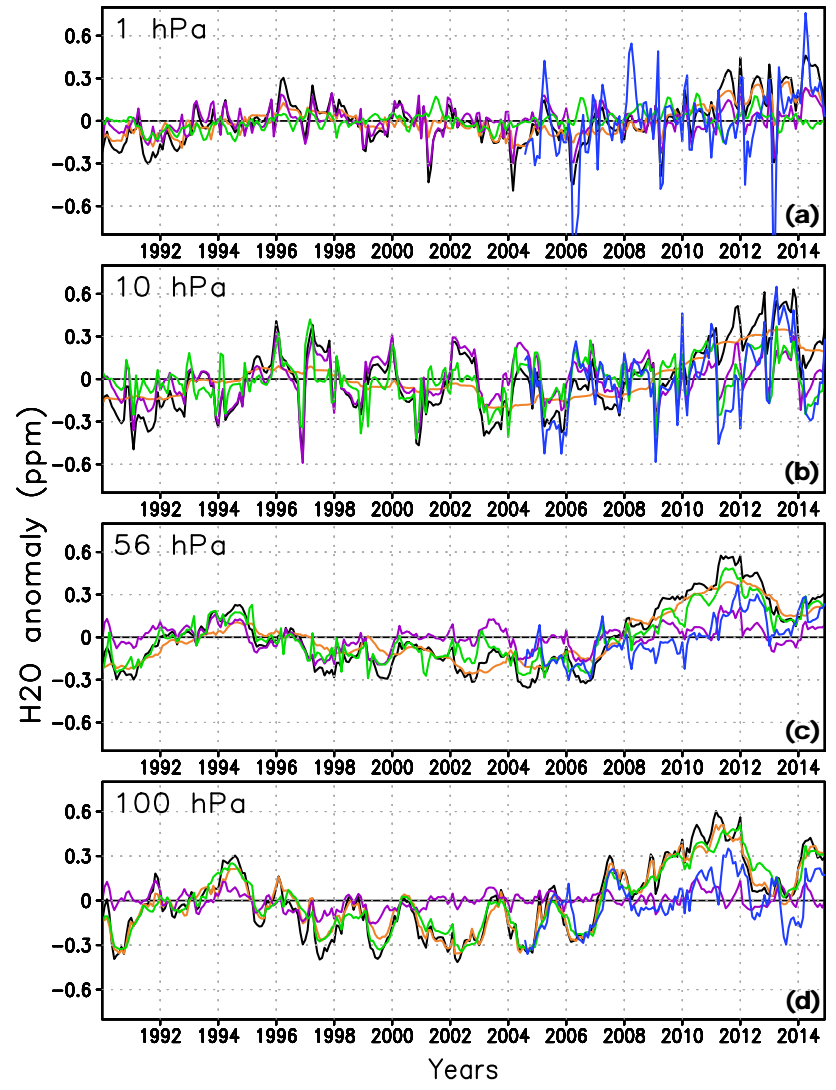

Figure 5. Panel (a): anomalies of water vapour (black), tracer describing transported water vapour (orange), tracer describing water produced by methane oxidation (purple) from FinROSE, and water vapour anomaly from ECMWF ERA-Interim (green) as parts per million in 1990-2014 and water vapour anomaly from MLS (blue) in 2004-2014. Anomalies are calculated at latitudes between 70$90^{\circ} \mathrm{N}$ at the level of $1 \mathrm{hPa}$. Panels (b-d): same as panel (a) but at levels of 10,56 , and $100 \mathrm{hPa}$.

tropics are similar to those in higher latitudes (not shown). The anomalies seen in FinROSE also agree with the results by Dessler et al. (2013) for tropical water vapour between 2005 and 2013.

The Arctic water vapour concentration in FinROSE increases by about $0.8 \mathrm{ppm}$ at an altitude of $56 \mathrm{hPa}$ from the year 2004 until the year 2012. This increase corresponds to a ca. $1 \mathrm{~K}$ increase in the frost point temperature (Marti and Mauersberger, 1993). However, the concentration during recent years (2012 to 2014) has decreased more than $0.5 \mathrm{ppm}$. The FinROSE water vapour anomaly and the passive tracer anomaly have nearly the same changes as the water vapour, in line with the results presented in Fig. 3. The evolution of the FinROSE water vapour anomaly is similar to the ERAInterim anomaly (green line), which is expected as FinROSE is driven by the ERA-Interim data. The chemical part (purple line), which is mainly due to the contribution of methane oxidation, has only a small positive trend consistent with previ- 
ous studies because the stratospheric methane concentration was nearly stable in the analysed time period.

In order to attribute water vapour changes to physical processes, we performed regression analysis following Dessler et al. (2014). We used three proxies: the QBO index (QBO, equatorial winds at $50 \mathrm{hPa}$ ), the Brewer-Dobson circulation index $(\mathrm{BD}$, residual vertical winds at $70 \mathrm{hPa}$ averaged from $30^{\circ} \mathrm{S}$ to $30^{\circ} \mathrm{N}$ ), and cold point temperature (CPT). Unlike Dessler et al. (2014) we found that the use of tropical temperatures at $500 \mathrm{hPa}$ was not enough to explain the variability of the cold point temperature, and we therefore used the cold point temperature as one of the proxies. Although there is some correlation between CPT and QBO (0.32), QBO also affects the transport of the water vapour not directly influenced by CPT; therefore, the use of both proxies is justified. We apply multiple regression analysis with all three proxies to water vapour time series averaged north of $70^{\circ} \mathrm{N}$ and at 82 and $56 \mathrm{hPa}$. Cross-correlation analysis shows broad peaks at lags of 6-12 months for the proxies. The maximum of the correlations of QBO and CPT with water vapour at $56 \mathrm{hPa}$ has a lag of about 10 months and that with $82 \mathrm{hPa}$ has a lag of 8-9-months, suggesting that propagation of the tropical anomalies in the lower stratosphere is faster than that in the middle stratosphere, likely due to more efficient mixing. We use a 10-month lag for all proxies for the regression at $56 \mathrm{hPa}$ and a 9-month lag for the regression at $82 \mathrm{hPa}$.

The individual correlation and regression coefficients with our proxies taken at the lags mentioned above are shown in the Table 1. The main contribution to the polar water vapour variability is CPT, followed by QBO. We found a very weak contribution of the $\mathrm{BD}$ proxy to the variability of the water vapour. One reason is that the effect of the $\mathrm{BD}$ contribution is accumulated over time, and this is not well represented by the monthly mean proxy. The multiple regression coefficients are 0.57 and 0.51 at $82 \mathrm{hPa}$ and at $56 \mathrm{hPa}$, respectively, showing that our models only explain $25-30 \%$ of the variability. This is considerably less than that of Dessler et al. (2014), suggesting that different processes contribute to the polar water vapour variability in comparison to those in the tropics. The modelled time series together with contributions of individual processes and residuals are shown in Fig. 6. It is seen that the cold point variability and QBO make comparable contributions to the water vapour variability at both levels. Note that the regression explains the increase in the water vapour from 2005 to 2010, which is clearer at $82 \mathrm{hPa}$, to some extent. However, the peak of the water vapour during 2011-2013 is not explained by these proxies.

\section{Arctic dehydration frequency}

In the polar vortex areas the concentration of water vapour can be changed also by dehydration. Water freezes into ice particles, sediments to lower altitudes, and sublimates. Dehydration is frequently observed in the Antarctic polar vor-
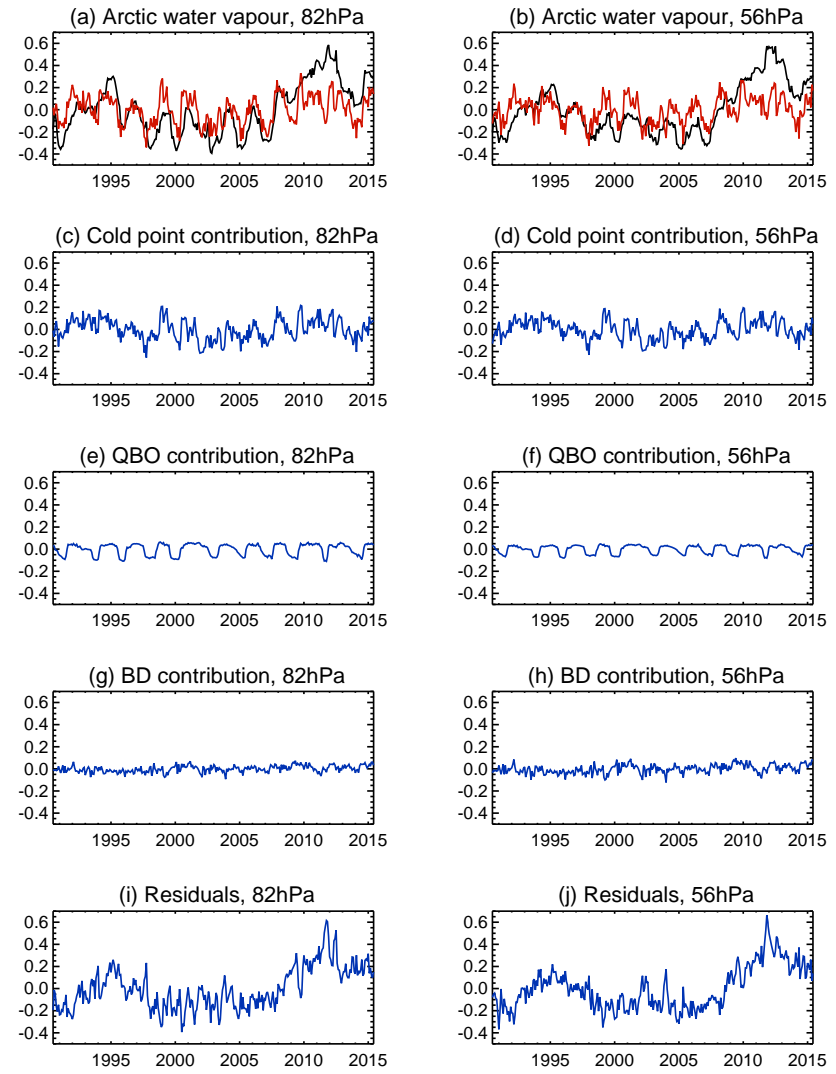

Figure 6. The contribution of individual processes to water vapour variability.

tex, and there the magnitude of decrease in the water vapour by dehydration is several parts per million. The water vapour mixing ratio can be reduced to $1.5 \mathrm{ppm}$ in the cold stable Antarctic vortex (Vömel et al., 1995). In the Arctic vortex dehydration is rare because the temperatures are higher. However, ice PSCs are formed also in the Arctic vortex, and it is possible for dehydration to occur (Khaykin et al., 2013).

Ice PSC formation is controlled by temperature and water vapour concentration, which both exhibit considerable variability. FinROSE simulates significant ice PSC conditions in the Arctic in 12 out of 25 winters $(1990,1993,1995,1996$, 2000, 2005, 2008, 2010, 2011, 2012, 2013, and 2014). This means that nearly $50 \%$ of winters offer conditions which allow the formation of ice PSCs. However, they cover only a small fraction of the vortex. The largest extent of simulated ice PSCs was seen in 1990, with an area of $3 \times 10^{6} \mathrm{~km}^{2}$ at $56 \mathrm{hPa}$. In 1993, 2005, 2011, 2012, and 2014 an area of around $2.5 \times 10^{6} \mathrm{~km}^{2}$ was reached. Figure 7 shows the area of the grid points where ice PSC (black) forms in the FinROSE model and the minimum temperature of the area between 50 and $90^{\circ} \mathrm{N}$ at $56 \mathrm{hPa}$ level. From 2007 onwards the ice PSC areas from CALIPSO lidar observations are shown as comparison (red). Based on the time series in Fig. 7, it seems that there is an increase in ice PSCs in the recent win- 


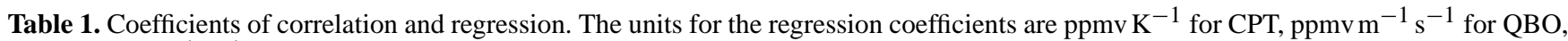
and $\mathrm{ppmv} \mathrm{mm}^{-1} \mathrm{~s}^{-1}$. Regression coefficients are shown together with the $95 \%$ confidence intervals.

\begin{tabular}{llrrrr}
\hline & & CPT & QBO & BD & Multiple \\
\hline \multirow{2}{5}{$6 \mathrm{hPa}$} & Correlation & 0.45 & 0.32 & -0.21 & 0.51 \\
& Regression & $0.12 \pm 0.03$ & $0.003 \pm 0.002$ & $-1.51 \pm 0.83$ & - \\
\hline \multirow{2}{*}{$82 \mathrm{hPa}$} & Correlation & 0.52 & 0.40 & -0.18 & 0.57 \\
& Regression & $0.13 \pm 0.03$ & $0.004 \pm 0.002$ & $-1.15 \pm 0.80$ & -
\end{tabular}

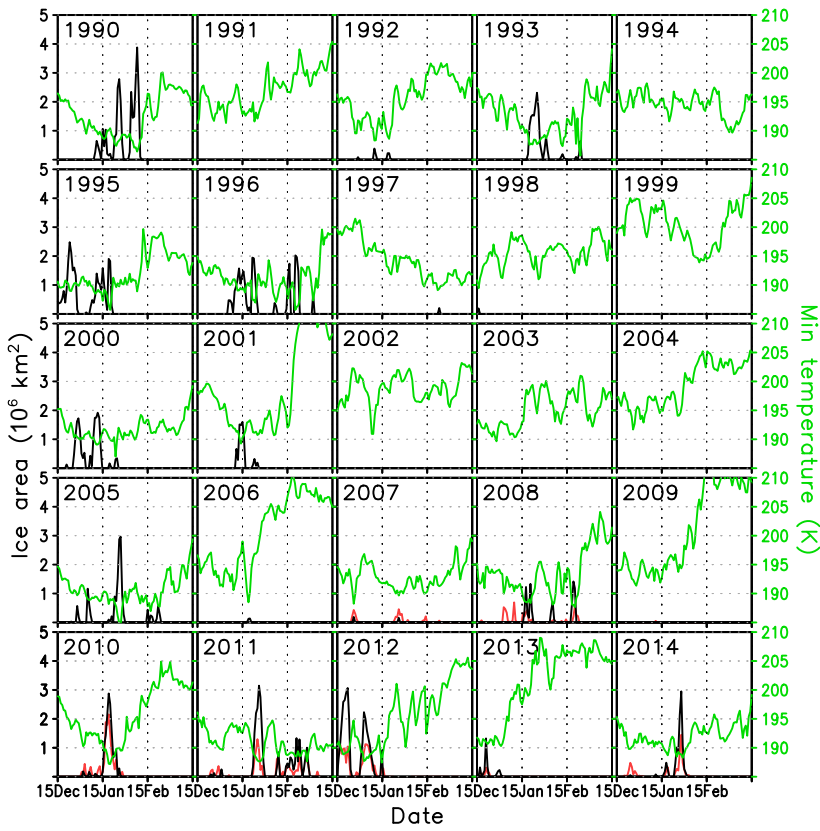

Figure 7. The area where ice PSCs formed in the FinROSE simulation (black) and were observed by CALIPSO (red) and the minimum temperature between $50-90^{\circ} \mathrm{N}$ from ERA-Interim (green, right $y$ axis) for winters between 1990 and 2014 at $56 \mathrm{hPa}$.

ters. Between 2007 and 2014 there are six ice PSC winters in FinROSE and seven winters in CALIPSO, which leads to frequency of 0.75 ( 0.87 for CALIPSO), considerably higher than the mean frequency for the whole studied period. This is likely a combined effect of cold conditions and the increase in the water vapour concentration. Another period with frequent ice PSC occurrence was between 1990 and 1996 when ice PSCs occurred in four out of seven winters. The temperature conditions were cold in the beginning of the $90 \mathrm{~s}$, but water vapour concentrations were lower than in the 2000s. The PSC areas in FinROSE agree well with the ones calculated from CALIPSO data. However, in some cases, e.g. the beginning of winters, CALIPSO detects PSCs that are not simulated by FinROSE. This may indicate a warm bias in ERA-Interim in that period. Also, in 2007 CALIPSO detects ice PSCs which are not seen in the model. This may be due to the resolution of the model $\left(3^{\circ} \times 6^{\circ}\right.$, latitude $\times$ longitude $)$, as the areas are quite small.

Figure 8, left panel, shows the relation of the area of simulated and observed ice PSCs and the area with air colder than $188 \mathrm{~K}$ temperatures in December-February at the level of $56 \mathrm{hPa}$. One point, or X, denotes 1 winter day between 2007 and 2014 in the FinROSE simulation or the CALIPSO observation. The colour of the marks shows the water vapour concentration averaged in the vortex. Figure 8, right panel, shows the dependence of ice PSC on water vapour. It can be seen that while temperature is the main factor controlling the ice PSC formation, the formation also noticeably depends on water vapour concentration. Higher water vapour concentrations produce larger areas of ice PSC, but in a dry vortex, no ice PSCs form even when the temperature is low enough. The effect of both temperature and water vapour on ice PSC area is also seen in Table 2: for similar temperature conditions, the ice PSC area increases when water vapour concentration increases. This holds for cases when areas with temperature below $188 \mathrm{~K}$ are small or large and is seen in both FinROSE and CALIPSO. Consistent with expectations, the correlation between cold temperature area and ice PSC area are 0.89 for FinROSE and 0.64 for CALIPSO. The correlations between water vapour and ice PSC is 0.30 in FinROSE and 0.35 in CALIPSO, both statistically significant at the $5 \%$ level. CALIPSO detects small ice PSC areas with small cold temperature areas, but in the case of FinROSE, the ice PSCs are not always created although the cold temperature area is large. The increase in water vapour in the vortex area was about $0.8 \mathrm{ppm}$ after 2007. That would have increased the ice PSC areas even if the temperatures were the same, consistent with earlier estimations by Kirk-Davidoff et al. (1999).

\section{Case study: the winter of 2009/2010}

The winter of 2009/2010 was unusually cold in the Arctic polar region. The temperature was below $190 \mathrm{~K}$ in a large area of the polar vortex. In the lower stratosphere temperatures below $195 \mathrm{~K}$ were observed even south of $60^{\circ} \mathrm{N}$. PSCs were formed and even persistent dehydration was observed over northern polar latitudes for the first time (Khaykin et al., 2013). Cold conditions favouring PSC formations lasted until the end of January 2010. A major sudden stratospheric warm- 
Table 2. Monthly mean ice PSC areas $\left(10^{6} \mathrm{~km}^{2}\right)$ in FinROSE (left) and CALIPSO (right) at $56 \mathrm{hPa}$ pressure level as a function of $56 \mathrm{hPa}$ monthly mean water vapour concentration $(\mathrm{ppm})$ averaged north of $60^{\circ} \mathrm{N}$ and the area of temperatures below $188 \mathrm{~K}\left(10^{6} \mathrm{~km}{ }^{2}\right)$. The number of months in each group is shown in parentheses.

\begin{tabular}{lrrrrrrr}
\hline \multicolumn{9}{c}{ Water vapour (ppm) } \\
\hline $\begin{array}{l}\text { Area } T<188 \mathrm{~K} \\
\left(10^{6} \mathrm{~km}^{2}\right)\end{array}$ & \multicolumn{3}{c}{ FinROSE } & & \multicolumn{3}{c}{ CALIPSO } \\
\cline { 2 - 4 } \cline { 6 - 8 } & Wet $(>5.4)$ & $5.2-5.4$ & Dry $(<5.2)$ & & Wet $(>5.4)$ & $5.2-5.4$ & Dry $(<5.2)$ \\
\hline Warm $(0.5-1.5)$ & $1.61(10)$ & $1.09(10)$ & $0.31(4)$ & & $0.70(4)$ & $0.46(9)$ & $0.18(2)$ \\
\hline Cold $(1.5-3.0)$ & $2.49(10)$ & $2.48(10)$ & $1.28(4)$ & & $0.96(4)$ & $1.20(9)$ & $0.24(2)$ \\
\hline
\end{tabular}

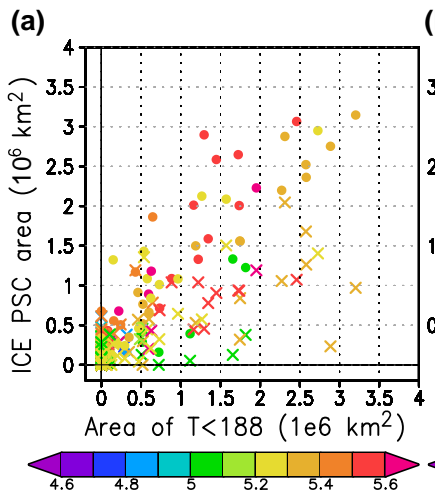

(b)

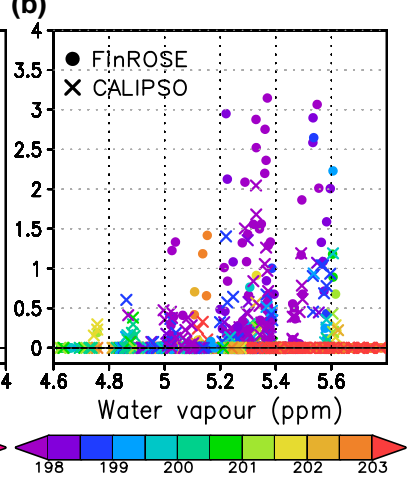

(ppm)

(K)

Figure 8. Panel (a): scatter plot of December-February ice PSC area versus the area colder than $188 \mathrm{~K}$ in the Northern Hemisphere from FinROSE and CALIPSO at $56 \mathrm{hPa}$. The colour denotes the vortex mean water vapour content (ppm). Panel (b): scatter plot of the December-February ice PSC area versus the vortex mean water vapour content (ppm) from FinROSE and CALIPSO at $56 \mathrm{hPa}$. The colour denotes the vortex average temperature (K). FinROSE is shown with dots and CALIPSO is shown with crosses.

ing (SSW) took place at the end of January, centred around 24 January (e.g. Khaykin et al., 2013; Dörnbrack et al., 2012; Pitts et al., 2011). Following the SSW, stratospheric temperatures rose above the PSC formation threshold so that no more PSCs were observed during that winter.

We use the winter of 2009/2010 as a case study and compare FinROSE simulations of water vapour and ice PSC to observations (see Figs. 9 and 10).

Figure 9 shows the area of ice PSCs from CALIPSO (top panel) and from FinROSE (middle panel) and the area of temperatures colder than $188 \mathrm{~K}$ (lower panel) in the Arctic winter of 2009/2010. Ice PSCs occur at the coldest dates and the same time both in the FinROSE simulation and CALIPSO observations. The ice PSC areas in the beginning of January 2010 are smaller in FinROSE than in CALIPSO, but after mid-January the areas are larger in FinROSE than in CALIPSO. However, the clouds appear at the same altitudes in the model as in observations. The timing is also compa-
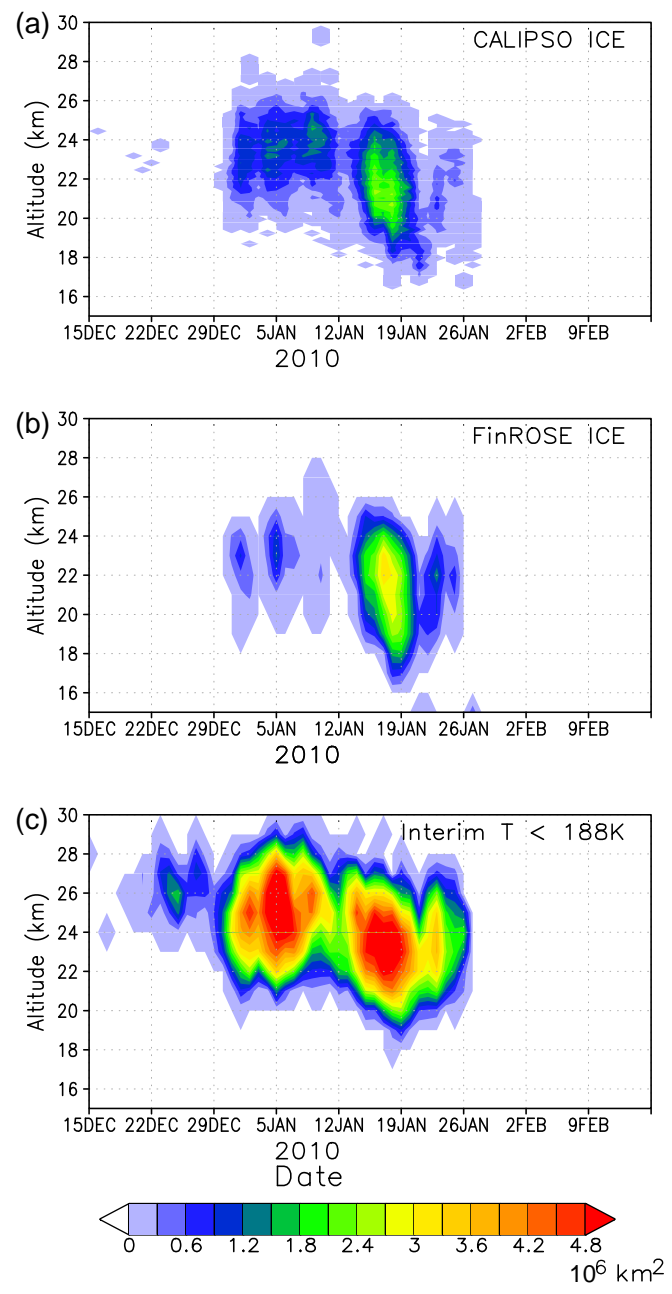

Figure 9. Ice PSC area from CALIPSO (a), ice PSC area from FinROSE (b), and (c) area colder than $188 \mathrm{~K}$ from ECMWF ERAInterim in the winter of 2009/2010.

rable. The differences may be attributed to the model coarse resolution and the simplicity of the PSC parameterization. The area of cold temperatures in the lowest panel is larger than the modelled and observed ice PSC areas. 


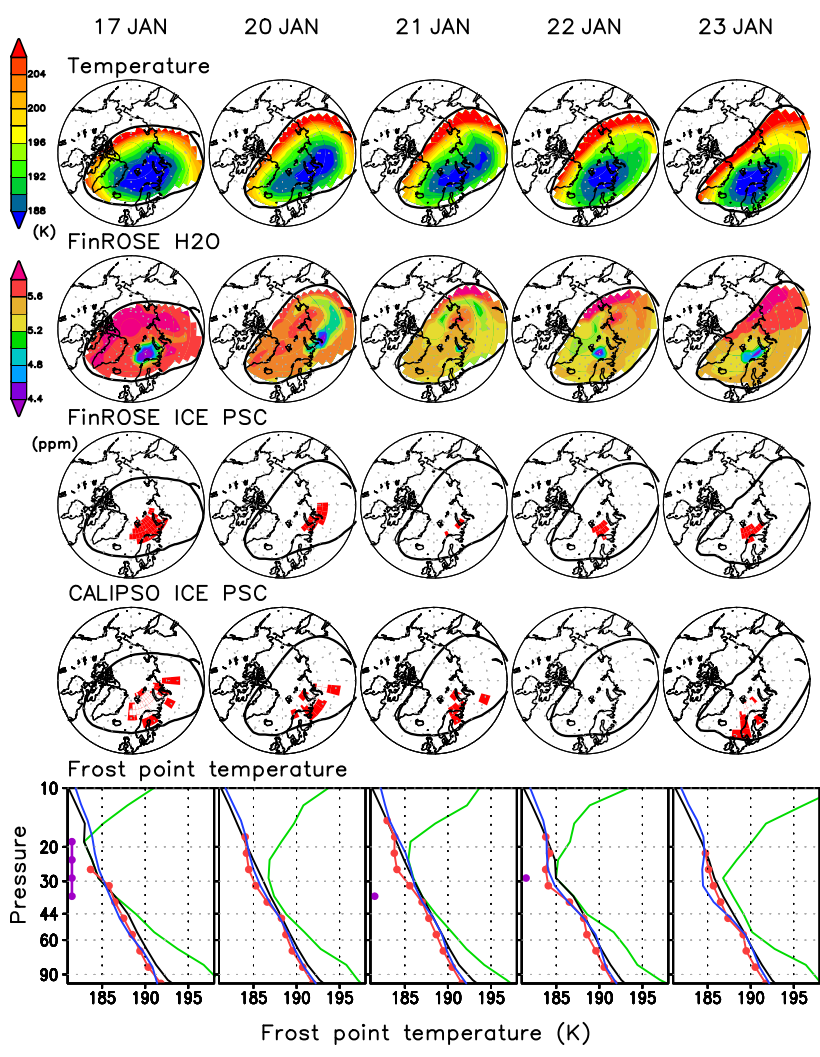

Figure 10. Upper four rows: temperature, water vapour (ppm), and ice PSC occurrence from FinROSE and ice PSC occurrence from CALIPSO during the extreme cold period of the winter of 2010. The black contour marks the border of the vortex defined as modified potential vorticity $(\mathrm{PV})>36$. All maps are at the $35 \mathrm{hPa}$ pressure level. Lowest row: ERA-Interim temperature (green) and frost point temperature from Sodankylä soundings (red dots), from MLS (blue), and from FinROSE (black). Purple dots shows the altitudes where FinROSE simulated ice PSC.

Figure 10 shows maps of temperature from ERA-Interim, the water vapour mixing ratio from FinROSE, and ice PSC from FinROSE and CALIPSO from Northern Hemisphere vortex area at the sounding dates between 17 and 23 January 2010 at the level $35 \mathrm{hPa}(24 \mathrm{~km})$. The level $35 \mathrm{hPa}$ was chosen because it was the coldest level with large ice PSCs. The minimum temperatures in the vortex (first row) are very low in this time period, even below $188 \mathrm{~K}$. The water vapour mixing ratio from FinROSE (second row) is the highest at the vortex boundary and the lowest in the middle of the vortex. Areas with very cold temperatures correlate with very low water vapour content areas because of the ice PSC formation. On 17 January the driest areas coincide both in space and time with the coldest temperatures. The water vapour is frozen and condensed into ice particles, and as time progresses, ice particles grow and sediment downwards, resulting in dehydrated air masses. The sedimentation of ice particles results in a redistribution of water vapour. On 2023 January the dehydrated air masses, where no ice is present around the pole, but the minimum water vapour values do not coincide with coldest temperatures.

Figure 10 shows that at $35 \mathrm{hPa}$ ice PSCs were simulated by FinROSE in the same areas as they were observed by CALIPSO. To facilitate the comparison, CALIPSO observations have been gridded to a grid of $5 \times 10^{\circ}$, and the grid box is marked as having ice PSC if there was at least one ice PSC observation within the grid box area. CALIPSO measures only single orbits and the gridded data appear sparse. Note that each day CALIPSO orbits cover only a part of the globe; therefore, observations appear sparse. Nevertheless, it can be seen that the grid boxes where CALIPSO observed ice PSC are scattered over larger areas in comparison to FinROSE simulations

The bottom row in Fig. 10 shows modelled frost point temperature profiles above Sodankylä from FinROSE and temperature profiles from ECMWF ERA-Interim analysis, frost point temperature calculated from MLS satellite water vapour, and frost point temperature from Sodankylä soundings. The FinROSE output at $30^{\circ} \mathrm{E}, 69^{\circ} \mathrm{N}$, located next to Sodankylä $\left(26.6^{\circ} \mathrm{E}, 67.4^{\circ} \mathrm{N}\right)$, is shown. Overall, FinROSE can simulate the frost point temperature quite well. The ECMWF ERA-Interim temperature reaches or almost reaches the frost point temperature during the analysed time period. Then the formation of ice PSC is possible also in FinROSE. The coldest date in Sodankylä is 1 January. Very low frost point temperature values can also be seen above $40 \mathrm{hPa}$ altitudes after 17 th; this is likely a result of dehydration. This can be seen both in observations and in FinROSE. The water vapour concentration decreases about 1 to $1.5 \mathrm{ppm}$ from the median values. A small increase in water vapour observed below $40 \mathrm{hPa}$ on 23 January is interpreted as rehydration. It is not simulated by FinROSE at the grid point shown, but is simulated at other cold grid points near Sodankylä (not shown). In summary, FinROSE was able to reproduce stratospheric water vapour and ice PSC evolution well during the record coldest period in the winter of 2010.

\section{Conclusions}

FinROSE has been shown to be capable of simulating the water vapour distribution and evolution in the northern highlatitude stratosphere. The representation of water vapour in FinROSE is improved compared to the ERA-Interim data, even though the ERA-Interim data are used as a tropospheric boundary condition. The full chemistry in FinROSE produces more water than the simplified parameterization of ECMWF ERA-Interim, alleviates the dry bias of ERAInterim, and improves the comparison with observations. The model gives results comparable to the MLS satellite measurements. However, some discrepancies compared to the MLS remain.

The concentration of stratospheric water vapour in FinROSE is too high, especially in the summer time. Compared 
to the Sodankylä frost point hygrometer, the model is too moist. However, the number of comparisons is limited. In addition, some of the soundings have been made in the vicinity of the polar vortex, which further complicates comparison with the model data.

The main sources of the stratospheric water vapour are transport from the tropical troposphere and methane oxidation. A passive tracer was used in the FinROSE model to investigate the relative importance of the different sources of water vapour. The chemically produced fraction shows a maximum at altitudes between 6 and $0.3 \mathrm{hPa}$. At these altitudes in the summertime, the photochemical part is nearly as big as the transported part.

The considerable decadal variability can be seen in water vapour below $10 \mathrm{hPa}$; water vapour increases between 2007 and 2012 by about $0.8 \mathrm{ppm}$ in 5 years, which is followed by a decrease. In the upper stratosphere the increase is smaller than in the lower stratosphere. In the MLS data the increase is smaller than seen in FinROSE. The increase can be attributed to water vapour transported trough the tropical tropopause, while the contribution of the photochemically produced part of water vapour to the increase is negligible due to comparably smaller changes in the stratospheric methane concentration. A regression analysis suggests that cold point temperature variability and QBO make a comparable contribution to the Arctic water vapour variability in the lower stratosphere; however, they only explain $25-30 \%$ of the monthly variability.

In the FinROSE simulation ice PSCs occurred in northern high latitudes in 12 out of 25 simulated winters. Comparison with the CALIPSO instrument, which measured PSCs since 2006, shows that FinROSE simulates PSCs generally at the same time as observed by CALIPSO. Also, the area of ice PSC occurrence is comparable to the CALIPSO observations.

Ice PSCs became more frequent in the recent years of the simulation. While cold temperatures observed during these years favoured ice PSC formations, our results suggest that increased stratospheric water vapour concentration in high latitudes may have increased the ice PSC occurrence after the year 2006.

Finally, as a test of the faithfulness of FinROSE simulations, we perform a case study of the extremely cold winter of 2009/2010. FinROSE is able to reproduce ice PSC extent and associated dehydration and rehydration at lower altitudes in good agreement with the observations reported by Khaykin et al. (2013). FinROSE is also able to reproduce the observed magnitude of the dehydration associated with ice PSC formation, which is about $1 \mathrm{ppm}$. These results add credibility to FinROSE's ability to reproduce stratospheric water vapour changes.
Acknowledgements. We want to thank the UARS reference atmosphere project and MLS Aura teams for water vapour data and the Atmospheric Science Data Center for the CALIPSO data. The MLS data were obtained through the Aura MLS website (http://mirador.gsfc.nasa.gov/). CALIPSO data were obtained from the NASA Langley Research Center Atmospheric Science Data Center. The Sodankylä water vapour sounding providers are also thanked. The funding from the Academy of Finland through the UTLS project (140408) is gratefully acknowledged.

Edited by: P. Jöckel

\section{References}

Atkinson, R., Baulch, D. L., Cox, R. A., Crowley, J. N., Hampson, R. F., Hynes, R. G., Jenkin, M. E., Rossi, M. J., and Troe, J.: Evaluated kinetic and photochemical data for atmospheric chemistry: Volume III - gas phase reactions of inorganic halogens, Atmos. Chem. Phys., 7, 981-1191, doi:10.5194/acp-7-981-2007, 2007.

Bates, D. R. and Nicolet, M.: The photochemistry of water vapor, J. Geophys. Res., 55, 301-327, 1950.

Bekki, S. and Pyle, J.: Two-dimensional assessment of the impact of aircraft sulphur emissions on the stratospheric sulphate aerosol layer, J. Geophys. Res., 9, 15839-15847, 1992.

Brewer, A. W.: Evidence for a world circulation provided by the measurements of helium and water vapor distribution in the stratosphere, Q. J. Roy. Meteor. Soc., 75, 351-363, 1949.

Carslaw, K. S., Luo, B., and Peter, T.: An analytic expression for the composition of aqueous $\mathrm{HNO}_{3}-\mathrm{H}_{2} \mathrm{SO}_{4}$ stratospheric aerosols including gas phase removal of $\mathrm{HNO}_{3}$, Geophys. Res. Lett., 22, 1877-1880, 1995.

Dameris, M., Godin-Beekmann, S., Alexander, S., Braesicke, P., Chipperfield, M., de Laat, A. T. J., Orsolini, Y., Rex, M., and Santee, M. L.: Update on Polar ozone: Past, present, and future, Chapter 3 in Scientific Assessment of Ozone Depletion: 2014, Global Ozone Research and Monitoring Project - Report No. 55, World Meteorological Organization, Geneva, Switzerland, 2014.

Damski, J., Thölix, L., Backman, L., Taalas, P., and Kulmala, M.: FinROSE - middle atmospheric chemistry and transport model, Boreal Environ. Res., 12, 535-550, 2007.

Dee, D. P., Uppala, S. M., Simmons, A. J., Berrisford, P., Poli, P., Kobayashi, S., Andrae, U., Balmaseda, M. A., Balsamo, G., Bauer, P., Bechtold, P., Beljaars, A. C. M., van de Berg, L., Bidlot, J., Bormann, N., Delsol, C., Dragani, R., Fuentes, M., Geer, A. J., Haimberger, L., Healy, S. B., Hersbach, H., Holm, E. V., Isaksen, L., Kallberg, P., Kohler, M., Matricardi, M., McNally, A. P., Monge-Sanz, B. M., Morcrette, J.-J., Park, B.-K., Peubey, C., de Rosnay, P., Tavolato, C., Thepaut, J.-N., and Vitart, F.: The ERA-Interim reanalysis: configuration and performance of the data assimilation system, Q. J. Roy. Meteor. Soc., 137, 553-597, 2011.

Dethof, A.: Aspects of modelling and assimilation for the stratosphere at ECMWF, SPARC Newslett., 2, 11-14, 2003.

Deuber, B., Haefele, A., Feist, D. G., Martin, L., Kampfer, N., Nedoluha, G. E., Yushkov, V., Khaykin, S., Kivi, R., and Vömel, H.: Middle Atmospheric Watre Vapor Radiometer (MIAWARA): validation and first results of the LAPBIAT Up- 
per Tropospheric Lower Stratospheric Water Vapor Validation Project (LAUTLOS-WAVVAP) campaign, J. Geophys. Res., 110, D13306, doi:10.1029/2004JD005543, 2005.

Dessler, A. E., Schoeberl, M. R., Wang, T., Davis, S. M., and Rosenlof, K. H.: Stratospheric water vapor feedback, P. Natl. Acad. Sci. USA, 45, 18087-18091, doi:10.1073/pnas.1310344110, 2013.

Dessler, A. E., Schoeberl, M. R., Wang, T., Davis, S. M., Rosenlof, K. H., and Vernier, J.-P.: Variations of stratospheric water vapor over the past three decades, J. Geophys. Res., 119, 12588-12598, doi:10.1002/2014JD021712, 2014.

Dörnbrack, A., Pitts, M. C., Poole, L. R., Orsolini, Y. J., Nishii, K., and Nakamura, H.: The 2009-2010 Arctic stratospheric winter general evolution, mountain waves and predictability of an operational weather forecast model, Atmos. Chem. Phys., 12, 36593675, doi:10.5194/acp-12-3659-2012, 2012.

Dye, J. E., Baumgardner, D., Gandrud, B. W., Kawa, S. R., Kelly, K. K., Loewenstein, M., Ferry, G. V., Chan, K. R., and Gary, B. L.: Particle size distributions in arctic polar stratospheric clouds, growth and freezing of sulfuric acid droplets, and implications for cloud formation, J. Geophys. Res., 97, 8015-8034, 1992.

Engel, I., Luo, B. P., Khaykin, S. M., Wienhold, F. G., Vömel, H., Kivi, R., Hoyle, C. R., Grooß, J.-U., Pitts, M. C., and Peter, T.: Arctic stratospheric dehydration - Part 2: Microphysical modeling, Atmos. Chem. Phys., 14, 3231-3246, doi:10.5194/acp-143231-2014, 2014.

EOS MLS Science Team: MLS/Aura Level 2 Water Vapor $\left(\mathrm{H}_{2} \mathrm{O}\right)$ Mixing Ratio,version 003, Greenbelt, MD, USA, NASA Goddard Earth Science Data and Information Services Center, available at: http://disc.sci.gsfc.nasa.gov/datacollection/ML2H2O_ V003.html (last access: 15 April 2015), 2011.

Fahey, D. W., Kelly, K. K., Kawa, S. R., Tuck, A. F., Loewenstein, M., Chan, K. R., and Heidt, L. E.: Observations of denitrification and dehydration in the winter polar stratospheres, Nature, 344, 321-324, doi:10.1038/344321a0, 1990.

Fahey, D. W., Gao, R. S., Carslaw, K. S., Kettleborough, J., Popp, P. J., Northway, M. J., Holecek, J. C., Ciciora, S. C., McLaughlin, R. J., Thompson, T. L., Winkler, R. H., Baumgardner, D. G., Gandrud, B., Wennberg, P. O., Dhaniyala, S., McKinney, K., Peter, Th., Salawitch, R. J., Bui, T. P., Elkins, J. W., Webster, C. R., Atlas, E. L., Jost, H., Wilson, J. C., Herman, R. L., Kleinböhl, A., and von König, M.: The detection of large nitric-acid particles in the winter Arctic stratosphere, Science, 291, 1026-1031, 2001.

Gettelman, A., Birner, T., Eyring, V., Akiyoshi, H., Bekki, S., Brühl, C., Dameris, M., Kinnison, D. E., Lefevre, F., Lott, F., Mancini, E., Pitari, G., Plummer, D. A., Rozanov, E., Shibata, K., Stenke, A., Struthers, H., and Tian, W.: The Tropical Tropopause Layer 1960-2100, Atmos. Chem. Phys., 9, 16211637, doi:10.5194/acp-9-1621-2009, 2009.

Grooß, J.-U., Engel, I., Borrmann, S., Frey, W., Günther, G., Hoyle, C. R., Kivi, R., Luo, B. P., Molleker, S., Peter, T., Pitts, M. C., Schlager, H., Stiller, G., Vömel, H., Walker, K. A., and Müller, R.: Nitric acid trihydrate nucleation and denitrification in the Arctic stratosphere, Atmos. Chem. Phys., 14, 1055-1073, doi:10.5194/acp-14-1055-2014, 2014.

Hanson, D. and Mauersberger, K.: Vapor pressures of $\mathrm{HNO}_{3} / \mathrm{H}_{2} \mathrm{O}$ solutions at low temperatures, J. Phys. Chem., 92, 6167-6170, 1988.
Hegglin, M., Tegtmeier, S., Anderson, J., Froidevaux, L., Fuller, R., Funke, B., Jones, A., Lingenfelser, G., Lumpe, J., Pendlebury, D., Remsberg, E., Rozanov, A., Toohey, M., Urban, J., von Clarmann, T., Walker, K. A., Wang, R., and Weigel, K.: SPARC Data Initiative: comparison of water vapor climatologies from international satellite limb sounders, J. Geophys. Res., 118, 1182411846, doi:10.1002/jgrd.50752, 2013.

Hegglin, M. I., Plummer, D. A., Shepherd, T. G., Scinocca, J. F., Anderson, J., Froidevaux, L., Funke, B., Hurst, D., Rozanov, A., Urban, J., von Clarmann, T., Walker, K. A., Wang, H. J., Tegtmeier, S., and Weigel, K.: Vertical structure of stratospheric water vapour trends derived from merged satellite data, Nat. Geosci., 7, 768-776, doi:10.1038/ngeo2236, 2014.

Hintsa, E. J., Newman, P. A., Jonsson, H. H., Webster, C. R., May, R. D., Herman, R. L., Lait, L. R., Schoeberl, M. R., Elkins, J. W., Wamsley, P. R., Dutton, G. S., Bui, T. P., Kohn, D. W., and Anderson, J. G.: Dehydration and denitrification in the Arctic polar vortex during the 1995-1996 winter, Geophys. Res. Lett., 25, 501-504, 1998.

Hurst, D. F., Oltmans, S. J., Vömel, H., Rosenlof, K. H., Davis, S. M., Ray, E. A., Hall, E. G., and Jordan, A. F.: Stratospheric water vapor trends over Boulder, Colorado: analysis of the 30 year Boulder record, J. Geophys. Res., 116, D02306, doi:10.1029/2010JD015065, 2011.

Karpechko, A., Lukyanov, A., Kyrö, E., Khaikin, S., Korshunov, L., Kivi, R., and Vömel, H.: The water vapour distribution in the Arctic lowermost stratosphere during the LAUTLOS campaign and related transport processes including stratospheretroposphere exchange, Atmos. Chem. Phys., 7, 107-119, doi:10.5194/acp-7-107-2007, 2007.

Kelly, K. K., Tuck, A. F., Murphy, D. M., Proffitt, M. H., Fahey, D. W., Jones, R. L., Mckenna, D. S., Loewenstein, M., Podolske, J. R., Strahan, S. E., Ferry, G. V., Chan, K. R., Vedder, J. F., Gregory, G. L., Hypes, W. D., Mccormick, M. P., Browell, E. V., and Heidt, L. E.: Dehydration in the lower Antarctic stratosphere during late winter and early spring, 1987, J. Geophys. Res, 94, 11317-11357, doi:10.1029/JD094iD09p11317, 1989.

Khaykin, S. M., Engel, I., Vömel, H., Formanyuk, I. M., Kivi, R., Korshunov, L. I., Krämer, M., Lykov, A. D., Meier, S., Naebert, T., Pitts, M. C., Santee, M. L., Spelten, N., Wienhold, F. G., Yushkov, V. A., and Peter, T.: Arctic stratospheric dehydration - Part 1: Unprecedented observation of vertical redistribution of water, Atmos. Chem. Phys., 13, 11503-11517, doi:10.5194/acp13-11503-2013, 2013.

Kirk-Davidoff, D. B., Anderson, J. G., Hintsa, E. J., and Keith, D. W.: The effect of climate change on ozone depletion through changes in stratospheric water vapour, Nature, 402, 399401, 1999.

Kirner, O., Müller, R., Ruhnke, R., and Fischer, H.: Contribution of liquid, NAT and ice particles to chlorine activation and ozone depletion in Antarctic winter and spring, Atmos. Chem. Phys., 15, 2019-2030, doi:10.5194/acp-15-2019-2015, 2015.

Kivi, R., Vömel, H., Immler, F., Lehtola, T., Kämpfer, N., Straub, C., Yushkov, V., Khaykin, S., Christensen, T., and Wienhold, F. G.: LAPBIAT atmospheric sounding campaign in 2010, upper-air and remote sensing observations of water vapour, in: WMO Technical Conference on Meteorological and Environmental Instruments and Methods of Observation (TECO-2010), 
Helsinki, Finland, 30 August-1 September 2010, Instruments and Observing System Methods Report No. 104, WMO/TD-No. 1546, 2010.

Krämer, M., Müller, R., Bovensmann, H., Burrows, J., Brinkmann, J., Röth, E.-P., Grooß, J.-U., Müller, R., Woyke, T., Ruhnke, R., Günther, G., Hendricks, J., Lippert, E., Carslaw, K. S., Peter, T., Zieger, A., Brühl, C., Steil, B., Lehmann, R., and McKenna, D. S.: Intercomparison of stratospheric chemistry models under polar vortex conditions, J. Atmos. Chem., 45, 51-77, 2003.

Kunz, A., Spelten, N., Konopka, P., Müller, R., Forbes, R. M., and Wernli, H.: Comparison of Fast In situ Stratospheric Hygrometer (FISH) measurements of water vapor in the upper troposphere and lower stratosphere (UTLS) with ECMWF (re)analysis data, Atmos. Chem. Phys., 14, 10803-10822, doi:10.5194/acp14-10803-2014, 2014.

Kylling, A., Albold, A., and Seckmeyer, G.: Transmittance of a cloud is wavelength - dependent in the UV-range: physical interpretation, Geophys. Res. Lett., 24, 397-400, doi:10.1029/97GL00111, 1997.

Lambert, A., Read, W. G., Livesey, N. J., Santee, M. L., Manney, G. L., Froidevaux, L., Wu, D. L., Schwartz, M. J., Pumphrey, H. C., Jimenez, C., Nedoluha, G. E., Cofield, R. E., Cuddy, D. T., Daffer, W. H., Drouin, B. J., Fuller, R. A., Jarnot, R. F., Knosp, B. W., Pickett, H. M., Perun, V. S., Snyder, W. V., Stek, P. C., Thurstans, R. P., Wagner, P. A., Waters, J. W., Jucks, K. W., Toon, G. C., Stachnik, R. A., Bernath, P. F., Boone, C. D., Walker, K. A., Urban, J., Murtagh, D., Elkins, J. W., and Atlas, E.: Validation of the Aura Microwave Limb Sounder middle atmosphere water vapor and nitrous oxide measurements, J. Geophys. Res., 112, D24S36, doi:10.1029/2007JD008724, 2007.

Langematz, U., Meul, S., Grunow, K., Romanowsky, E., Oberläder, S., Abalichin, J., and Kubin A.: Future Arctic temperature and ozone: The role of stratospheric composition changes, J. Geophys. Res.-Atmos., 119, 2092-2112, doi:10.1002/2013JD021100, 2014.

Le Texier, H., Solomon, S., and Garcia, R. R.: The role of molecular hydrogen and methane oxidation in the water vapour budget of the stratosphere, Q. J. Roy. Meteor. Soc., 114, 281-295, 1988.

Lin, S.-J. and Rood, R. B.: Multidimensional flux-form semilagrangian transport schemes, Mon. Weather Rev., 124, 20462070, 1996.

Marti, J. and Mauersberger, K.: A survey and new measurements of ice vapor pressure at temperatures between 170 and $250 \mathrm{~K}$, Geophys. Res. Lett., 20, 363-366, doi:10.1029/93GL00105, 1993.

McLinden, C. A., McConnell, J. C., McElroy, C. T., and Griffioen, E.: Observations of stratospheric aerosol using CPFM polarized limb radiances, J. Atmos. Sci., 56, 233-240, 1999.

Monge-Sanz, B. M., Chipperfield, M. P., Untch, A., Morcrette, J.J., Rap, A., and Simmons, A. J.: On the uses of a new linear scheme for stratospheric methane in global models: water source, transport tracer and radiative forcing, Atmos. Chem. Phys., 13, 9641-9660, doi:10.5194/acp-13-9641-2013, 2013.

Montzka, S. A., Butler, J. H., Elkins, J. W., Thompson, T. M., Clarke, A. D., and Lock, L. T.: Present and future trends in the atmospheric burden of ozone-depleting halogens, Nature, 398, 690-694, 1999.

Oltmans, S. J.: Measurements of water vapor in the stratosphere with a frost point hygrometer, measurement and control in sci- ence and industry, in: Proceedings of the 1985 International Symposium on Moisture and Humidity, Instrument Society of America, Washington, DC, 251-258, 1985.

Oltmans, S. J., Vömel, H., Hofmann, D. J., Rosenlof, K. H., and Kley, D.: The increase in stratospheric water vapor from balloonborne, frostpoint hygrometer measurements at Washington, D. C., and Boulder, Colorado, Geophys. Res. Lett., 27, 3453-3456, doi:10.1029/2000GL012133, 2000.

Pitts, M. C., Thomason, L. W., Poole, L. R., and Winker, D. M.: Characterization of Polar Stratospheric Clouds with spaceborne lidar: CALIPSO and the 2006 Antarctic season, Atmos. Chem. Phys., 7, 5207-5228, doi:10.5194/acp-7-5207-2007, 2007.

Pitts, M. C., Poole, L. R., Dörnbrack, A., and Thomason, L. W.: The 2009-2010 Arctic polar stratospheric cloud season: a CALIPSO perspective, Atmos. Chem. Phys., 11, 2161-2177, doi:10.5194/acp-11-2161-2011, 2011.

Prinn, R. G., Weiss, R. F., Fraser, P. J., Simmonds, P. G., Cunnold, D. M., Alyea, F. N., O'Doherty, S., Salameh, P., Miller, B. R., Huang, J., Wang, R. H. J., Hartley, D. E., Harth, C., Steele, L. P., Sturrock, G., Midgley, P. M., and McCulloch, A.: A history of chemically and radiatively important gases in air deduced from ALE/GAGE/AGAGE, J. Geophys. Res., 105, 1775117792, 2000.

Randel, W., Wu, F., Oltmans, S., Rosenlof, K., and Nedoluha, G.: Interannual changes in stratospheric water vapor and correlations with tropical tropopause temperatures, J. Atmos. Sci., 61, 2133 2148, 2004.

Rex, M., Salawitch, R. J., Deckelmann, H., von der Gathen, P., Harris, N. R. P., Chipperfield, M. P., Naujokat, B., Reimer, E., Allaart, M., Andersen, S. B., Bevilacqua, R., Braathen, G. O., Claude, H., Davies, J., De Backer, H., Dier, H., Dorokhov, V., Fast, H., Gerding, M., Godin-Beekmann, S., Hoppel, K., Johnson, B., Kyrö, E., Litynska, Z., Moore, D., Nakane, H., Parrondo, M. C., Risley, A. D., Skrivankova, P., Stübi, R., Viatte, P., Yushkov, V., and Zerefos, C.: Arctic winter 2005: Implications for stratospheric ozone loss and climate change, Geophys. Res. Lett., 33, L23808, doi:10.1029/2006GL026731, 2006.

Rieder, H. E. and Polvani, L. M.: Are recent Arctic ozone losses caused by increasing greenhouse gases?, Geophys. Res. Lett., 40, 4437-4441, 2013.

Sander, S. P., Abbatt, J., Barker, J. R., Burkholder, J. B., Friedl, R. R., Golden, D. M., Huie, R. E., Kolb, C. E., Kurylo, M. J., Moortgat, G. K., Orkin, V. L., and Wine, P. H.: Chemical Kinetics and Photochemical Data for Use in Atmospheric Studies, Evaluation No. 17, JPL Publication 10-6, Jet Propulsion Laboratory, Pasadena, USA, 2011.

Scherer, M., Vömel, H., Fueglistaler, S., Oltmans, S. J., and Staehelin, J.: Trends and variability of midlatitude stratospheric water vapour deduced from the re-evaluated Boulder balloon series and HALOE, Atmos. Chem. Phys., 8, 1391-1402, doi:10.5194/acp8-1391-2008, 2008.

Schmidt, G. A., Ruedy, R. A., Miller, R. L., and Lacis, A. A.: Attribution of the present-day total greenhouse effect, J. Geophys. Res., 115, D20106, doi:10.1029/2010JD014287, 2010.

Schoeberl, M. R., Dessler, A. E., and Wang, T.: Simulation of stratospheric water vapor and trends using three reanalyses, Atmos. Chem. Phys., 12, 6475-6487, doi:10.5194/acp-12-6475-2012, 2012. 
Shindell, D. T., Rind, D., end Lonergan, P.: Increased polar stratospheric ozone losses and delayed eventual recovery owing to increasing greenhouse-gas concentrations, Nature, 392, 589-592, 1998.

Simmons, A. J., Untch, A., Jakob, C., Kållberg, P., and Undén, P.: Stratospheric water vapour and tropical tropopause temperatures in ECMWF analyses and multi-year simulations, Q. J. Roy. Meteor. Soc., 125, 353-386, 1999.

Simmons, A. J., Uppala, S. M., Dee, D., and Kobayashi, S.: ERAInterim: new ECMWF reanalysis products from 1989 omwards, ECMWF Newslett., 110, 25-35, 2007.

Solomon, S.: Stratospheric ozone depletion: a review of concepts and history, Rev. Geophys., 37, 275-316, 1999.

Solomon, S., Garcia, R. R., Rowland, F. S., and Wuebbles, D. J.: On the depletion of Antarctic ozone, Nature, 321, 755-758, 1986.

Solomon, S., Rosenlof, K. H., Portmann, R. W., Daniel, J. S., Davis, S. M., Sanford, T. J., and Plattner, G.-K.: Contributions of stratospheric water vapor to decadal changes in the rate of global warming, Science, 327, 5970, 1219-1223, doi:10.1126/science.1182488, 2010.

Stiller, G. P., von Clarmann, T., Haenel, F., Funke, B., Glatthor, N., Grabowski, U., Kellmann, S., Kiefer, M., Linden, A., Lossow, S., and López-Puertas, M.: Observed temporal evolution of global mean age of stratospheric air for the 2002 to 2010 period, Atmos. Chem. Phys., 12, 3311-3331, doi:10.5194/acp-12-33112012, 2012.

Suortti, T. M., Kats, A., Kivi, R., Kämpfer, N., Leiterer, U., Miloshevich, L. M., Neuber, R., Paukkunen, A., Ruppert, P., Vömel, H., and Yushkov, V.: Tropospheric comparisons of Vaisala radiosondes and balloon-borne frost-point and lymanalpha hygrometers during the LAUTLOS-WAVVAP experiment, J. Atmos. Ocean. Tech., 25, 149-166, 2008.

Thölix, L., Backman, L., and Ojanen, S.-M.: The effects of driver data on the performance of the FinROSE chemistry transport model, Int. J. Remote Sens., 31, 6401-6408, 2010.
Tian, W. S., Chipperfield, M. P., and Lü, D. R.: Impact of increasing stratospheric water vapor on ozone depletion and temperature change, Adv. Atmos. Sci., 26, 423-437, doi:10.1007/s00376009-0423-3, 2009.

Urban, J., Lossow, S., Stiller, G., and Read, W.: Another drop in water vapor, Eos Trans. AGU, 94, 245-246, doi:10.1002/2014EO270001, 2014.

Vömel, H., Oltmans, S. J., Hofmann, D. J., Deshler, T., and Rosen, J. M.: The evolution of the dehydration in the Antarctic stratospheric vortex, J. Geophys. Res., 100, 13919-13926, 1995.

Vömel, H., Barnes, J., Forno, R., Fujiwara, M., Hasebe, F., Iwasaki, S., Kivi, R., Komala, N., Kyrö, E., Leblanc, T., Morel, B., Ogino, S.-Y., Read, W., Ryan, S. C., Saraspriya, S., Selkirk, H., Shiotani, M., Valverde-Canossa, J., and Whiteman, D.: Validation of Aura/MLS water vapor by balloon borne cryogenic frostpoint hygrometer measurements, J. Geophys. Res., 112, D24S37, doi:10.1029/2007JD008698, 2007a.

Vömel, H., David, D. E., and Smith, K.: Accuracy of tropospheric and stratospheric water vapor measurements by the cryogenic frost point hygrometer: instrumental details and observations, J Geophys. Res., 112, D08305, doi:10.1029/2006JD007224, $2007 b$.

Vömel, H., Yushkov, V., Khaykin, S., Korshunov, L., Kyrö, E., and Kivi, R.: Intercomparisons of Stratospheric Water Vapor Sensors: FLASH-B and NOAA/CMDL Frost-Point Hygrometer, J. Atmos. Ocean. Tech., 24, 941-952, 2007c.

Wohltmann, I., Wegner, T., Müller, R., Lehmann, R., Rex, M., Manney, G. L., Santee, M. L., Bernath, P., Suminska-Ebersoldt, O., Stroh, F., von Hobe, M., Volk, C. M., Hösen, E., Ravegnani, F., Ulanovsky, A., and Yushkov, V.: Uncertainties in modelling heterogeneous chemistry and Arctic ozone depletion in the winter 2009/2010, Atmos. Chem. Phys., 13, 3909-3929, doi:10.5194/acp-13-3909-2013, 2013. 